\title{
Examining the levels of ganglioside and cholesterol in cell membrane on attenuation the cytotoxicity of beta-amyloid peptide
}

\author{
Ming-Shen Lin ${ }^{\mathrm{a}}$, Liang-Yu Chen ${ }^{\mathrm{b}}$, Steven S.S. Wang ${ }^{\mathrm{c}}$, Yung Chang ${ }^{\mathrm{d}}$, Wen-Yih Chen ${ }^{\mathrm{a}, *}$ \\ a Department of Chemical and Materials Engineering, National Central University, Jhong-Li 320, Taiwan \\ ${ }^{\mathrm{b}}$ Department of Biotechnology, Ming-Chuan University, Gui-Shan 333, Taiwan

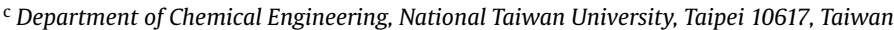 \\ d Center for Membrane Technology and Department of Chemical Engineering, Chung Yuan Christian University, Jhong-Li 320, Taiwan
}

\section{A R T I C L E I N F O}

\section{Article history:}

Received 27 November 2007

Received in revised form 25 March 2008

Accepted 30 March 2008

Available online 15 April 2008

\section{Keywords:}

$\beta$-Amyloid $(A \beta)$

Cholesterol

Ganglioside

Cytotoxicity

\begin{abstract}
A B S T R A C T
The deposition of $\beta$-amyloid $(A \beta)$ on cell membranes is considered as one of the primary factors in having Alzheimer's disease (AD). Recent studies have suggested that certain components of plasma membrane, ganglioside and cholesterol could accelerate the accumulation of $A \beta$ on the plasma membranes. However, the effect of cholesterol and ganglioside (GM1) on A $\beta$ cytotoxicity is still a controversial issue. The aim of this study is to understand the roles of GM1 and cholesterol in AD by using PC12, a neuron-like cell. The effects of the sequence, conformation, and concentration of $A \beta$ on cytotoxicity were also investigated. Monomeric $A \beta$ could attack the plasma membrane resulting in cytotoxicity, however, fibrillar $A \beta$ was found to be less toxic. Our results showed that $A \beta(1-40)$ was more toxic than $A \beta(25-35)$ and the cytotoxicity of $A \beta$ was proportional to its concentration. Besides, the depletion of GM1 from plasma membrane, it would block the A $\beta$-induced cytotoxicity. Decreasing the cholesterol level by around 30\% could attenuate the cytotoxicity of $A \beta$. These findings validate our idea that the cholesterol could stabilize the lateral pressure derived from the formation of GM1-A $\beta$ complex on the membrane surface. Furthermore, both GM1 and cholesterol are essential in mechanism of $A \beta$ accumulation and could modulate the cytotoxicity of monomeric $A \beta$.
\end{abstract}

(C) 2008 Elsevier B.V. All rights reserved.

\section{Introduction}

Alzheimer's disease (AD) is the most common form of senile dementia, which affects approximately $10 \%$ of all individuals over 65 years of age and more than $50 \%$ of those who over 85 years [1]. It has created a large burden on the health care system in terms of both services and costs of over \$10B per year in the United States [2].

$\mathrm{AD}$ is one kind of protein conformational diseases, which accompany memory and recognition degeneration. $\beta$-Amyloid $(A \beta)$ is an amphiphilic peptide responsible for the development of extracellular senile plaques in the brain, which are considered as one of the key pathological hallmarks in $\mathrm{AD}[3]$. The main constituents of senile plaques are $A \beta(1-40)$ and $A \beta(1-42)$, which are normally derived from the amyloid precursor protein (APP), a constituent membrane protein in the brain [4]. The $A \beta$ molecule possesses a hydrophilic region (N-terminal) and a hydrophobic region (Cterminal), and can self-assemble to form aggregates with various

\footnotetext{
* Corresponding author. Tel.: +886 3422 7151x34222; fax: +886 34225258 . E-mail address: wychen@cc.ncu.edu.tw (W.-Y. Chen).
}

morphologies such as dimers, oligomers, filaments, protofibrils, and fibrils [5-12]. The conversion of nontoxic-monomeric $A \beta$ to toxic $A \beta$ rich in $\beta$-sheet structure by aggregation is considered to be the key step in the development of $\mathrm{AD}[11,12]$. The C-terminus (from residue 28) of $A \beta(1-40)$ showed a higher probability for $\beta$-sheet structure, which was the cause for cytotoxicity. Since $A \beta$ (25-35) possess a positively charged residue in the $\mathrm{N}$-terminal and hydrophobic amino acid residues in the C-terminal, it could form the toxic structure as that of $A \beta(1-40)$. In the previous studies, $A \beta$ (25-35) was most frequently used, because $A \beta$ (25-35) and $A \beta(1-40)$ have similar biological effects $[13,14]$. Therefore, in the present study, $A \beta(25-35)$ and $A \beta(1-40)$ were chosen to investigate the cytotoxicity.

Several evidences showed that $A \beta$ can directly induce cell death using MTT assay [15,16]. Moreover, Wirths et al. [17] analyzed axonal neuropathology in the brain and spinal cord of a transgenic mouse model with abundant intraneuronal $A \beta$ production and provided compelling evidence for axonal degeneration. In animal model, Fu et al. [18] examined the learning and memory functions in mice by injecting $A \beta$. The water maze performance demonstrated that $A \beta$ caused impairments in memory and cognitive ability. Such findings may relate to a certain component of cell membrane, such 
as ganglioside (GM1) [15,19,20] and cholesterol [20-22], which induce $A \beta$ to attack the cells leading to cell death and even dysfunction.

GM1 and cholesterol are two important constituents of the plasma membrane. GM1 are abundant in neuron cells and involve in important neurobiological events, such as neurodifferentiation, synaptogenesis and synaptic transmission [23]. Cholesterol is the most predominant sterol in the plasma membrane, which is related to numerous cellular functions such as lipid fluidity, receptor function, endocytosis, enzyme activity, etc. [24-26]. Several researches have demonstrated that monomeric $A \beta$ may preferentially bound to GM1 and serves as a seed on the plasma membrane, which results in promoting aggregation of other $A \beta s[20,27,28]$. However, long-term studies have not shown a consistent relationship between cholesterol levels in cell membrane and the cytotoxicity of $A \beta$. Some researchers have proposed that lower cholesterol level could make cell more vulnerable to the activity of $A \beta$ [29]. Others have postulated contrastive results $[15,16,30]$. These contradictions motivate us to analyze the role of neuronal cholesterol and GM1 in AD. Moreover, the study focused on the relationship between GM1 and cholesterol. It might be crucial to understand the correlation to the mechanisms of interaction between $A \beta$ and plasma membrane.

The aim of this study is to understand the roles of ganglioside and cholesterol in AD by using PC12, a neuron-like cell. The effects of the sequence, conformation and concentration of $A \beta$ on the cytotoxicity were also investigated. Furthermore, the causal relationship between GM1, cholesterol and $A \beta$ was discussed in detail. Both of these findings provide insights into the roles of ganglioside and cholesterol in the interaction between monomeric $A \beta$ or fibrillar $\mathrm{A} \beta$ and cell membranes.

\section{Materials and methods}

\subsection{Materials}

$A \beta$ (25-35) and $A \beta(1-40)$ were obtained from Sigma and Biosource International (Camarillo, CA), respectively. Horse serum, fetal bovine serum, penicillin and streptomycin were purchased from Gibco BRL (Gaithersburg, MD). Dulbecco's Modified Eagle's Medium (DMEM), methyl- $\beta$-cyclodextrin $(\mathrm{M} \beta C D)$ and all other chemicals were obtained from Sigma. Water was de-ionized at $18 \mathrm{M} \Omega$ and sterile filtered $(0.22 \mu \mathrm{m})$ before usage.

\subsection{Peptide preparation}

$A \beta(25-35)$ and $A \beta(1-40)$ peptides were prepared analogously to methods which consistently lead to peptides that are toxic to cultured cells [31]. For the destruction of preexisting secondary structures, the $A \beta$ peptides were dissolved in pure $1,1,1,3,3,3-$ hexafluor-2-propanol (HFIP) at room temperature. The $A \beta$ solution was freeze-dried in a vacuum oven. Then the lyophilized powder was dissolved in serum-containing medium as a monomeric $A \beta$ for the following experiments. Before each experiment, the monomeric $A \beta$ was tested by electrophoresis, $C D$ analysis and AFM imaging. The fibrillar $A \beta$ was prepared by incubating the monomeric $A \beta$ at $37^{\circ} \mathrm{C}$ with a stirring speed of $50 \mathrm{rpm}$ for $96 \mathrm{~h}$ in an incubator. The conformation of fibrillar $A \beta$ was identified by CD analysis and AFM images (Fig. 1).

\subsection{Cell culture and $A \beta$ treatment}

Rat pheochromocytoma cells (PC12) were cultured in DMEM containing $5 \%(\mathrm{v} / \mathrm{v})$ horse serum, $10 \%(\mathrm{v} / \mathrm{v})$ fetal bovine serum, $3 \mathrm{mM}$ L-glutamine, 100 units $/ \mathrm{mL}$ penicillin, and $0.1 \mathrm{mg} / \mathrm{mL}$ streptomycin in a $5 \%(\mathrm{v} / \mathrm{v}) \mathrm{CO}_{2} /$ air environment at $37^{\circ} \mathrm{C}$. For determination of
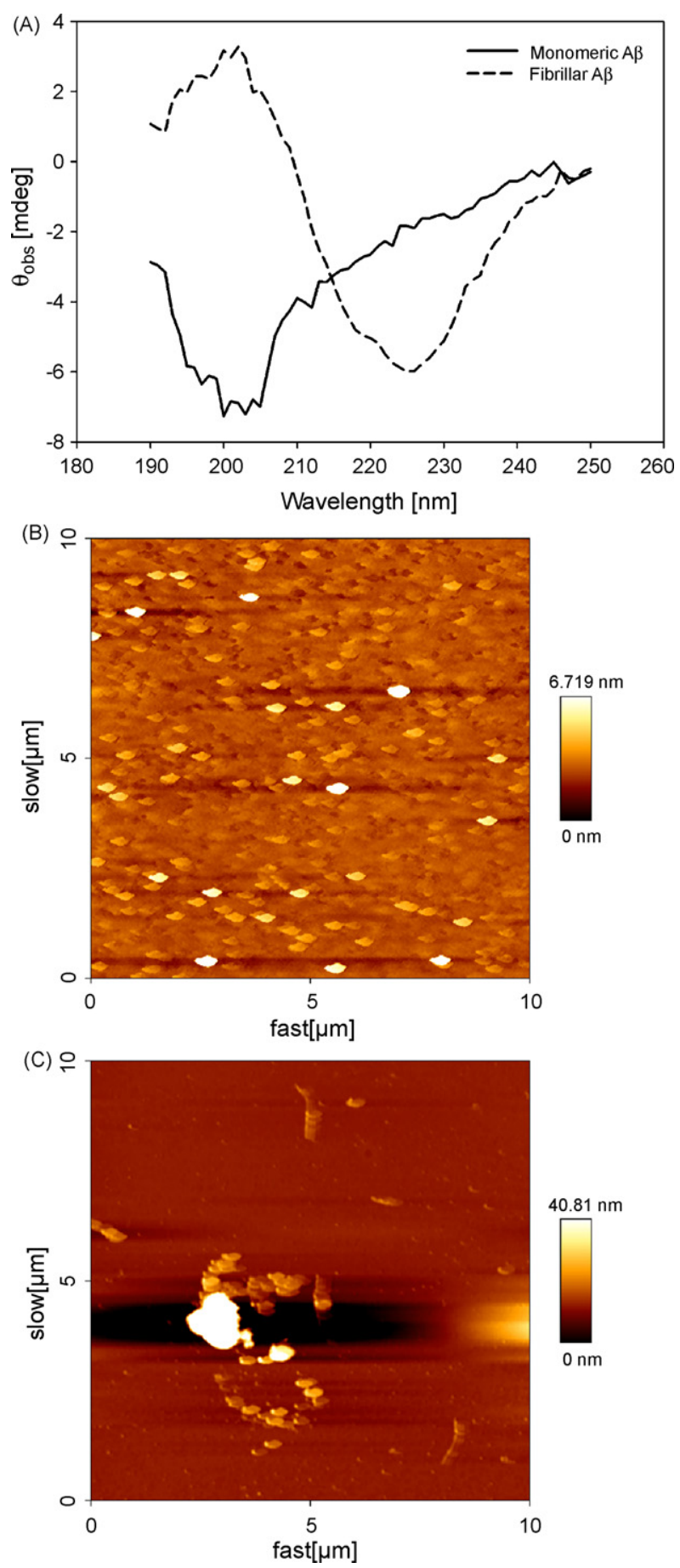

Fig. 1. (A) CD spectra of $20 \mu \mathrm{M} \mathrm{A \beta}(1-40)$ incubated in phosphate buffer, pH 7 at $37^{\circ} \mathrm{C}$. (B) AFM image of monomeric $A \beta(10 \mu \mathrm{m} \times 10 \mu \mathrm{m})$. (C) AFM image of fibrillar $\mathrm{A} \beta(10 \mu \mathrm{m} \times 10 \mu \mathrm{m})$.

cytotoxicity of $A \beta$ peptides, PC12 was initially plated in 96-well plates at the density of 10,000 cells/well and maintained for $12 \mathrm{~h}$ in the medium. The cells were then treated with enzymes to modulate the content of cell plasma. Subsequently, the cells were incubated with $A \beta$ for $24 \mathrm{~h}$. The cell viability was analyzed by MTT assay.

\subsection{Change in membrane cholesterol and synthesis inhibition}

To enrich the cholesterol content of the membrane, PC12 cells were incubated in a cholesterol-enriched medium [29]. Water- 
soluble cholesterol was first dissolved in de-ionized water at a concentration of $10 \mathrm{mg} / \mathrm{mL}$ and then added to the culture medium. Cells were incubated for $2 \mathrm{~h}$ in the media containing soluble cholesterol and washed with cholesterol-free media before the addition of $A \beta$. Under these conditions, the cellular cholesterol level was increased to $30 \%$ versus that in untreated cells. The cholesterol content of the PC12 surface membranes was decreased by M $\beta C D$. The plated PC12 cells were incubated for $3 \mathrm{~h}$ in serum-free medium and then treated with $10 \mathrm{mMM} \beta \mathrm{CD}$ in serum-free medium for $60 \mathrm{~min}$ at $37^{\circ} \mathrm{C}$. The $\mathrm{M} \beta \mathrm{CD}$-containing medium was then removed from cells and replaced by fresh serum-containing medium with the peptide for the MTT toxicity assays. $\mathrm{M} \beta \mathrm{CD}$ has been demonstrated to specifically remove cellular cholesterol $[15,20,22]$. Under these conditions, the cellular cholesterol level was reduced to $30-40 \%$ of that in untreated cells [22,29]. Alternatively, the plated PC12 cells were treated with $0.2 \mu \mathrm{g} / \mathrm{mL}$ filipin complex or $1 \mu \mathrm{M}$ compactin in medium and incubated for $48 \mathrm{~h}$ at $37^{\circ} \mathrm{C}$ prior to the peptide addition for the toxicity assays. Filipin has been reported to form complexes with cholesterol and compactin has been demonstrated to inhibit cholesterol production [15]. Control cells were treated identically except for the presence of peptide.

\subsection{Sialic acid depletion and ganglioside synthesis inhibition}

Membrane-associated sialic acids from gangliosides and cell surface glycoproteins were removed from cells similar to the established procedures [15]. The plated PC12 cells were incubated for $3 \mathrm{~h}$ in a serum-free medium, and then treated with 11.7 milliunits of $V$. cholerae neuraminidase and 3.3 milliunits of $A$. ureafaciens neuraminidase in a serum-free medium for $1 \mathrm{~h}$ at $37^{\circ} \mathrm{C}$ prior to the toxicity assays of the peptide or epinephrine addition. To inhibit cellular ganglioside re-synthesis, PC12 cells were treated with $20 \mu \mathrm{M}$ fumonisin B1 in medium and incubated for $48 \mathrm{~h}$ at $37^{\circ} \mathrm{C}$ prior to the peptide addition for the toxicity assays. Fumonisin B1 has been reported to inhibit cellular ganglioside synthesis. Control cells were treated identically except for the presence of peptide.

\subsection{MTT reduction assay}

The mitochondrial dehydrogenase activity that reduces 3-(4,5dimethyithiazol-2-yl)-2,5-diphenyl-tetrazolium bromide (MTT) was used to determine cellular redox activity, an initial indicator of cell death in a quantitative colorimetric assay. PC12 cells cultured in 96 -well plates at a density of 10,000 cells/well were exposed to

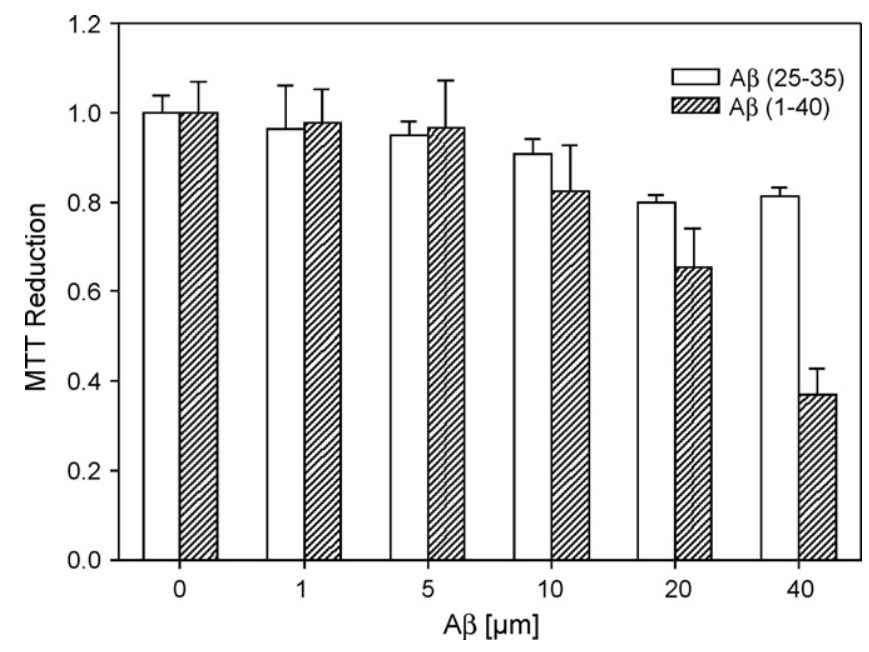

Fig. 2. Effect of the concentration of monomeric $A \beta$ on cell viability. $\beta$-amyloid peptide at various concentrations for $24 \mathrm{~h}$. Thereafter, PC 12 cells were incubated to the growth medium with MTT $(5 \mathrm{mg} / \mathrm{mL})$ for $4 \mathrm{~h}$ at $37^{\circ} \mathrm{C}$. The medium was then aspirated and the MTT reduction product, formazan was dissolved in dimethyl sulfoxide(DMSO) and quantified spectrophotometrically at $540 \mathrm{~nm}$. MTT reduction was expressed as percentage of control \pm S.E.M. from at least five independent experiments.

\section{Results}

\subsection{The effects of sequence, conformation and concentration of $A \beta$ on the cytotoxicity}

The cytotoxic effects of $A \beta(25-35)$ and $A \beta(1-40)$ on PC12 cells are shown in Fig. 2 . The unobvious cytotoxicity of $A \beta$ (25-35) and $A \beta$ (1-40) were observed at low $A \beta$ concentrations. On the contrary, a dramatic increase in cytotoxicity was observed at higher $A \beta$ concentrations. As the concentration of $A \beta(1-40)$ was increased to $20 \mu \mathrm{M}$ and $40 \mu \mathrm{M}$, the MTT values were decreased to $65 \%$ and $37 \%$, respectively. Nevertheless, the MTT values were maintained at around $80 \%$ in $20 \mu \mathrm{M}$ and $40 \mu \mathrm{M}$ of $A \beta(25-35)$. The MTT values of $A \beta(25-35)$ and $A \beta(1-40)$ showed no noticeable difference at the concentrations below $10 \mu \mathrm{M}$. The results on cytotoxicity induced by monomeric and fibrillar $A \beta$ are shown in Fig. 3. The fibrillar $A \beta$ has almost no toxic effect even at higher concentration of $A \beta(1-40)$. However, the cytotoxicity was proportional to the concentration of monomeric $A \beta$ of both $A \beta$ (25-35) and $A \beta$ (1-40). Therefore, we can conclude that the higher concentration of monomeric $A \beta$ (1-40) could increase the possibility of cell damage. For the subsequent studies, we therefore focused only on MTT-sensitive A $\beta$ (1-40) at 20 and $40 \mu \mathrm{M}$ in the monomeric form.

\subsection{GM1 blocks $A \beta$-induced cytotoxicity}

In our previous studies, we have shown that GM1 was affected the behavior of monomeric $A \beta$ aggregated on the surface of the liposomes [31]. Therefore, the influence of GM1 on $A \beta$-induced cytotoxicity must be evaluated. To improve the accuracy, the inhibition of the GM1 re-synthesized from cells was performed by the addition of fumonisin B1 after depletion of sialic acid in GM1. As shown in Fig. 4, the reduction in sialic acid content results in inhi-

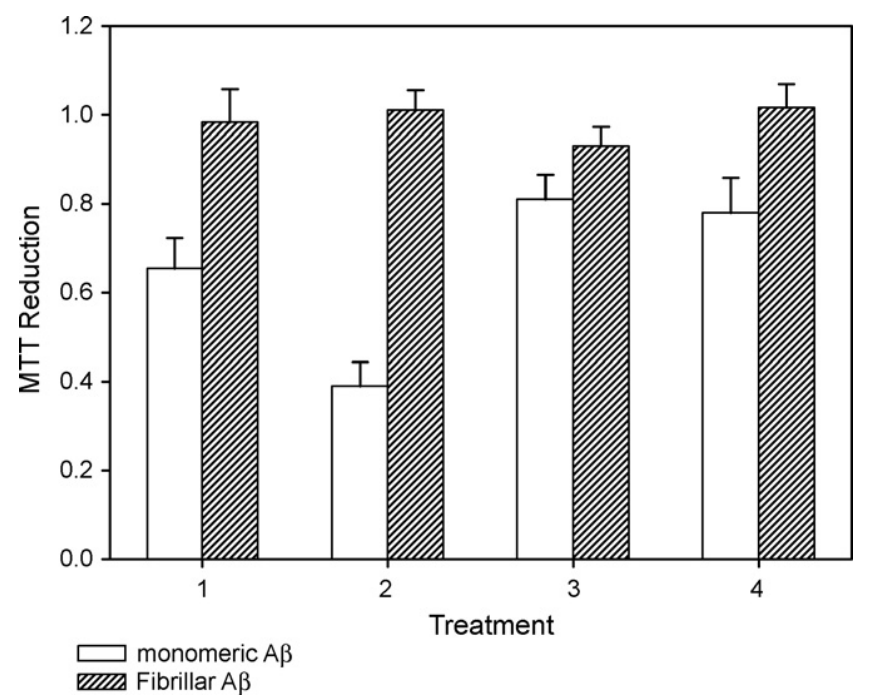

Fig. 3. Effect of the conformation of $A \beta$ on cell viability. Treatment $1: 20 \mu M A \beta$ (1-40); Treatment 2: $40 \mu \mathrm{M} \mathrm{A} \beta$ (1-40); Treatment 3: $20 \mu \mathrm{M} \mathrm{A} \beta$ (25-35); Treatment 4: $40 \mu \mathrm{M} \mathrm{A \beta}(25-35)$. 


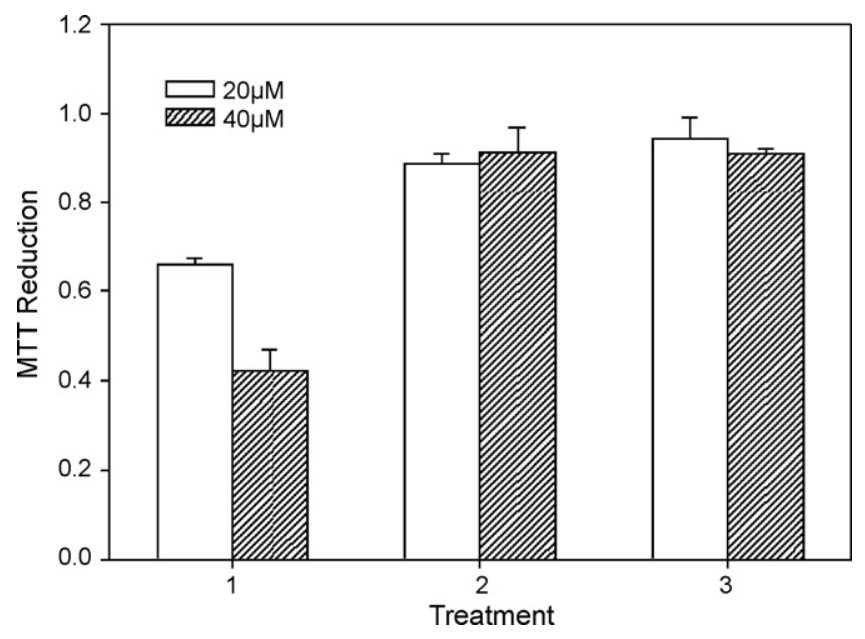

Fig. 4. Effect of GM1 and cholesterol depletion on the viability of monomeric $A \beta$ (1-40) treated PC12 cell. Treatment 1: control (normal cell); Treatment 2: GM1 depletion; Treatment 3: GM1 and cholesterol depletion.

bition of cytotoxicity induced by $A \beta$. In addition, the viability of cell decreases either in the presence of both sialic acid and cholesterol, or sialic acid alone, which indicates that GM1 is an essential factor in inducing the attack of $A \beta$ on the cell.

\subsection{Cholesterol modulates the A $\beta$-induced cytotoxicity}

To determine the possible involvement of membrane cholesterol in the interaction between $A \beta$ and plasma membrane, the modulation of cholesterol content on the plasma membrane was carried out to analyze the effect of cholesterol on cytotoxicity. Similar to the above investigation, the inhibition of the cholesterol re-synthesized from the cell was achieved by the addition of compactin and filipin after extracting the cholesterol by $M \beta C D$. Cholesterol is the predominant sterol in the plasma membrane and is necessary to stabilize the conformation of plasma membrane expected for cellular function [24-26]. Apoptosis or even death may be inevitable due to the excessive extraction of cholesterol from the surface plasma of cultured PC12 cells, which could affect subsequent studies. Therefore, the verification of the cell is necessary after the removal of cholesterol.

Experiments were performed to determine the optimum time for using $10 \mathrm{mM} \mathrm{M \beta CD}$ on PC12 cells as beyond certain time limit, it could affect the viability of PC12. Fig. 5 shows that after exposure over $60 \mathrm{~min}$, the $10 \mathrm{mM} \mathrm{M} \beta C D$ became toxic to cells. Therefore, to perform cholesterol extraction and keep the cell viability over $90 \%$ of the control cells, the cells were treated with $10 \mathrm{mM} \mathrm{M \beta CD}$ for $60 \mathrm{~min}$.

The effects of cholesterol levels on $A \beta$-induced cytotoxicity are shown in Fig. 6 . After incubation with $40 \mu \mathrm{M}$ monomeric $A \beta(1-40)$ for $24 \mathrm{~h}$, the MTT values for cells with decreased cholesterol contents was 0.57 and those with increased cholesterol contents was 0.28. It implies that reducing cholesterol content from plasma membrane could diminish the cytotoxicity induced by monomeric $A \beta$; inversely, higher cholesterol content could cause higher cytotoxicity. Besides, there was no significant difference in the effect of cholesterol levels on the cytotoxicity of fibrillar $A \beta$ as evident by MTT values that were in the range of $91 \%$.

\section{Discussion}

In our previous liposomal studies, the analysis of bio-molecular interactions between the $\beta$-amyloid and liposomes was character-

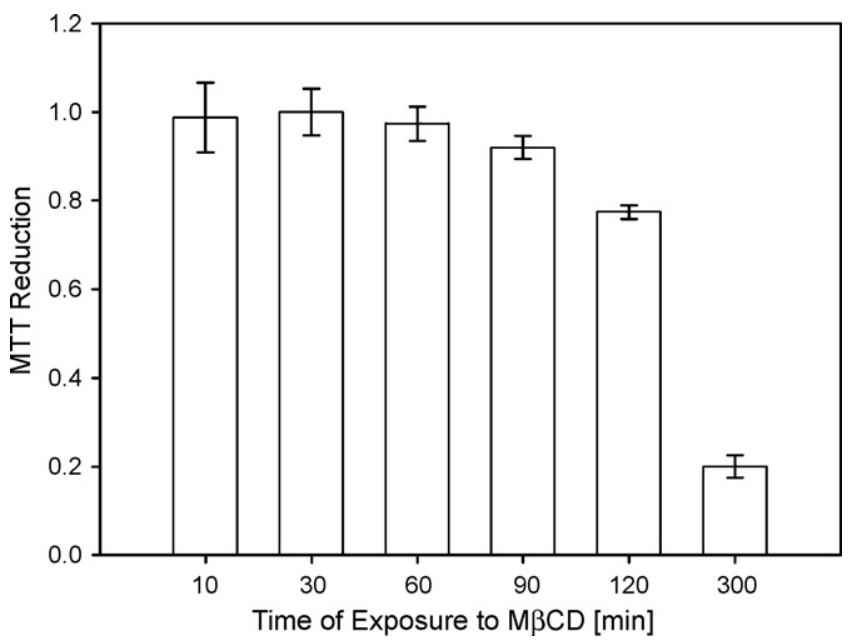

Fig. 5. Effect of $10 \mathrm{mM} M \beta C D$ extract on cell viability assayed by MTT test.

ized by surface plasmon resonance (SPR) and isothermal titration calorimetry (ITC) [31]. During $A \beta$ was adsorbed on the plasma membrane, both cholesterol and GM1 have essential roles. The present study was able to verify the previous assumption based on in vitro data, which reveals that the reduction of cholesterol and GM1 levels also affected the interaction between $A \beta$ and cell plasma. Recent studies suggested that $A \beta$ may not be toxic when deposited in amyloid plaques; instead, its neurotoxic properties might be attributed to the oligomeric or prefibrillar $A \beta$ aggregates $[11,12]$. This concept was supported by our observation that monomeric $A \beta$ could cause significant cytotoxicity. Synapse failure before neuron death has been considered to be caused by the accumulation of $A \beta$ oligomers rather than by amyloid fibrils [32]. Therefore, cell functions might degrade as monomeric $A \beta$ aggregate to form oligomer. Consistent with our previous kinetics data, monomeric $A \beta$ has a high affinity constant for interaction with the cell membrane, which implies that there is a higher adsorption of monomeric $A \beta$.

Other important factors could affect the aggregation rate of $A \beta$ are length of amino acid sequence and concentration. The longer the sequence of $A \beta$, the higher the potential it was to form the toxic conformation due to the presence of the more hydrophobic amino

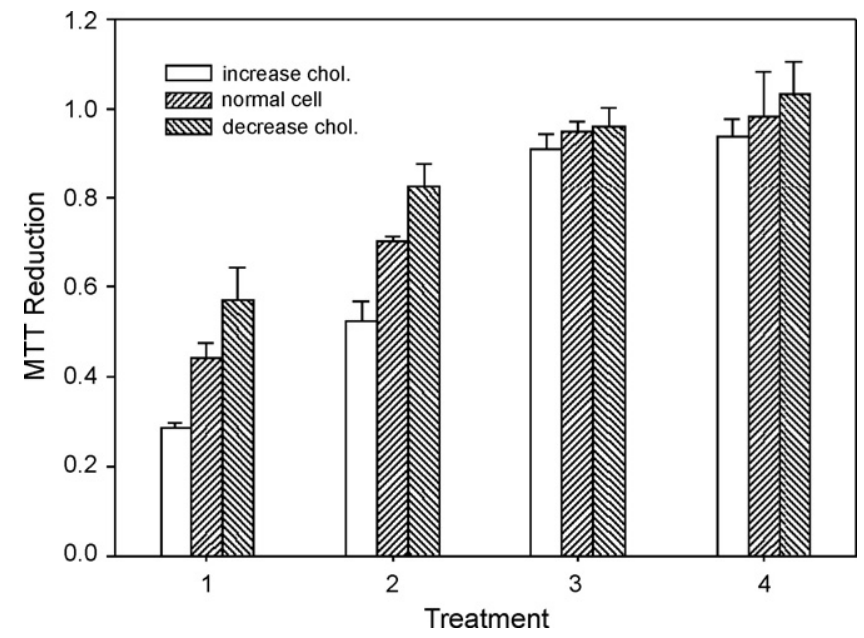

Fig. 6. Effect of cholesterol content on $A \beta$ (1-40) cytotoxicity. Treatment 1: $40 \mu \mathrm{M}$ monomeric $A \beta$ (1-40); Treatment 2: $20 \mu \mathrm{M}$ monomeric $A \beta$ (1-40); Treatment 3: $40 \mu \mathrm{M}$ fibrillar $\mathrm{A} \beta$ (1-40); Treatment 4: $20 \mu \mathrm{M}$ fibrillar $\mathrm{A} \beta$ (1-40). 
acid residues in the C-terminal. The probability of intermolecular collision could increase at higher $A \beta$ concentration, accelerating the formation of certain toxic and subsequent cell death. Thus, the significant cytotoxicity was seen in longer sequence and higher concentration, such as at $40 \mu \mathrm{M} \mathrm{A \beta}(1-40)$.

The exact mechanism(s) of AD was not fully understood so far and this is one of the factors for the non-availability of efficient drugs. However, increasing evidence indicated that the neuron cell membrane is important in the mechanism of $A \beta$ cytotoxicity. Studies have reported that membrane constituents, cholesterol and GM1, could alter the affinity of $A \beta$ for plasma membranes $[4,33,34]$. Monomeric or oligomeric $A \beta$ could aggregate on the cell membrane by electrostatic attractive force due to the negative charge of sialic acid in GM1. The presence of membrane could accelerate $A \beta$ aggregation. In addition, GM1-A $\beta$ complex that was formed as a seed, initiates a chain reaction to promote other $A \beta$ to accumulate on the plasma membrane [28]. Therefore, decreasing the amount of sialic acid by neuraminidase could effectively reduce the $A \beta$ cytotoxicity [15]. Unfortunately, synaptic plasma membranes have a relatively high concentration of GM1 with respect to other cellular membranes, and the loss of synapses was correlated well with the degree of $\mathrm{AD}$ [35].

Cholesterol has demonstrated that it could modulate $A \beta$ cytotoxicity. However, long-term studies have not observed a consistent relationship between cholesterol levels in cell membrane and the cytotoxicity of $A \beta$. In this study, changes in cholesterol levels in plasma membranes were correlated to $A \beta$ cytotoxicity. A decrease of around $30 \%$ cholesterol level could reduce the $A \beta$ cytotoxicity; likewise, an increase of around 30\% cholesterol level could induce higher $A \beta$ cytotoxicity. From in vitro studies, $A \beta$ might be induced to form fibril and cholesterol aggregation causing "phase separation" at high cholesterol level membranes [36], which rendered the cell to be unstable and so apoptosis or cell death was inevitable. Furthermore, cholesterol is related with $A \beta$ generation and $A \beta$ clearance [37]. At the steady state levels of all peptides in vivo are a direct consequence of the balance between their anabolism and catabolism; peptide accumulation can arise not only from increased production but also from less frequent breakdown. Arispe and Doh [29] revealed that PC12 cells became resistant to the cytotoxic action of $A \beta$ when incubated in a medium that enriches cholesterol levels of the surface membrane. However, in this study at higher concentration, monomeric $A \beta$ aggregated on the plasma membrane readily, which acted as seeds and increased the accumulation rate resulting in cytotoxicity by large quantity of $A \beta$ accumulated on the plasma membrane. The different findings from the previous studies was due to they have used very low $A \beta$ concentration. At this condition, the accumulation rate of seed formation is reduced when the catabolic rate on the cell membrane is higher than the accumulation rate. This resulted in catabolization of $A \beta$ on the plasma membrane to reduce the cytotoxicity. This could explain the differences in our results with those reported in the previous studies.

Though GM1 and cholesterol are considered as key factors in $A D$, the interaction between GM1, cholesterol and $A \beta$ are not clearly understood. Wakabayashi et al. [20] reported that cells with lesser GM1 could block the interaction of $A \beta$ and makes the distribution of GM1 less uniform resulting in the accumulation of few $A \beta s$ on the cholesterol-depleted cell membrane as observed from the confocal laser microscopy. We also utilized the NIMA Trough with fluorescence microscopy to observe the aggregation behavior in GM1 and cholesterol that were induced by $A \beta$ (data not shown). On the basis of the previous reports and the results obtained in the present study, we propose the "Recruiting Hypothesis" on the interaction between GM1, cholesterol and A $\beta$ (Fig. 7). The plasma membrane is composed of negatively charged GM1 along with neutral lipids (Fig. 7a).

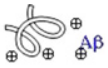

(a)

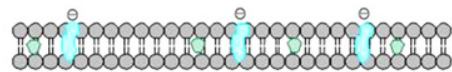

GM1 O: Cholesterol

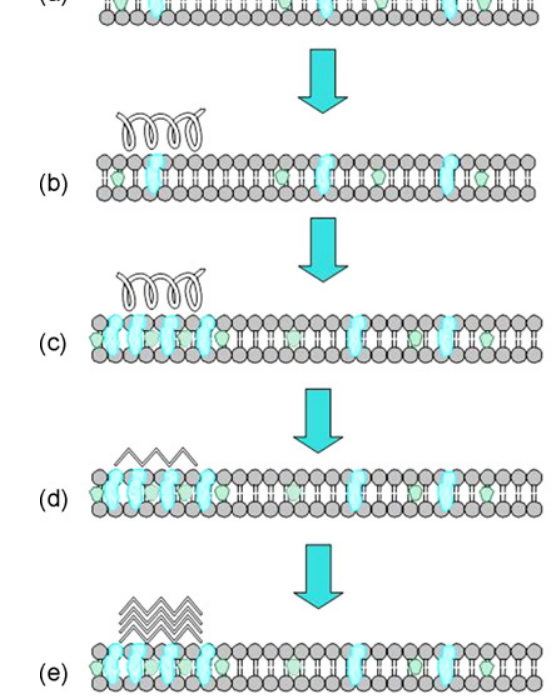

Fig. 7. Schematic representation of the interactions among GM1, cholesterol and $A \beta$. (a) Initially, $A \beta$ is in random coil structure and the plasma membrane is composed of negatively charged GM1 along with neural lipids. (b) $A \beta$ peptides are attracted by GM1 of the membrane and the conformation changed from random coil to $\alpha$-helix. (c) Formation of the GM1 cluster by electrostatic interaction between A $\beta$ and GM1 and cholesterol was recruited for stabilize the plasma membrane. (d) The $A \beta$ conformation changed from $\alpha$-helix to $\beta$-sheet, which acts as a seed. (e) The accumulation of $A \beta$ on the plasma membrane to form GM1-cholesterol-A $\beta$ clusters.

When the $A \beta$ peptide approaches on the surface of the plasma membrane, the positively charged monomeric $A \beta$ (Asp, Glu, Lys, Arg, His) are attracted by the negatively charged GM1 sites of the membrane and the conformation changed from random coil to $\alpha-$ helix (Fig. 7b). Due to the electrostatic attraction of more number of GM1 by the $A \beta$ leads to the formation of GM1 clusters (Fig. 7c). The GM1 clusters incurred the lateral rise in pressure of the membrane. In order to stabilize the cell membrane, cholesterol was recruited and it form raft-like structure to sustain the pressure and conformation of the membrane (Fig. 7c). Consequently, the $A \beta$ conformation changed from $\alpha$-helix to $\beta$-sheet (Fig. 7d), which acts as a seed and initiates a chain reaction, in that it attract other $A \beta$ s to interact with the GM1. This resulted in the accumulation of $A \beta$ on the plasma membrane (Fig. 7e). At the same time, both GM1 and cholesterol accumulate more and form larger clusters. Finally, each clusters aggregate with each other and form $A \beta, G M 1$ and cholesterol rich phase which resulted in the function of membrane degradation. Therefore, GM1 and cholesterol is necessary in A $\beta$ adsorption process. Understanding the insight of the relationship between GM1, cholesterol, and $A \beta$ could be useful in developing medicines and strategies aimed to cure AD.

\section{Conclusions}

The apparent discrepancy inspired us to analyze not only the roles of GM1 and cholesterol in AD but also the quantitative relationships among GM1, cholesterol, and $A \beta$. The results reported here demonstrated that lesser GM1 and cholesterol content could attenuate the $A \beta$ cytotoxicity. Besides, the semi-quantitative relationship in the interactions among GM1, cholesterol, and $A \beta$ might be a critical clue for the development of therapeutic strategies in AD. 


\section{Acknowledgments}

This work was supported by the National Science Council of the Republic of China via grant (NSC-95-2221-E-008-086) and VGHUST Joint Research Program, Tsou's Foundation (VGHUST 97-P3-07).

\section{References}

[1] K. Garber, Technol. Rev. 104 (2001) 70-77.

[2] S. Kar, P.M. Slowikowski Stephen, D. Westaway, T.J. Mount Howard, J. Psychiatry Neurosci. 291 (2004) 427-441.

[3] W.G. Wood, G.P. Eckert, U. Igbavboa, W.E. Muller, Biochem. Biophys. Acta 1610 (2003) 281-290

[4] D.J. Selkoe, Physiol. Rev. 81 (2001) 741-766.

[5] J.Y. Koh, L.L. Yang, C.W. Cotman, Brain Res. 553 (1990) 315-320.

[6] C.J. Pike, A.J. Walencewicz, C.G. Glabe, C.W. Cotman, Eur. J. Pharmacol. 207 (1991) 367-368.

[7] C.J. Pike, D. Burdick, A.J. Walencewicz, C.G. Glabe, C.W. Cotman, J. Neurosci. 13 (1993) 1676-1687.

[8] J. Busciglio, J. Yeh, B.A. Yankner, J. Neurochem. 61 (1993) 1565-1568.

[9] D.R. Howlett, K.H. Jennings, D.C. Lee, M.S. Clark, F. Brown, R. Wetzel, S.J. Wood, P. Camilleri, G.W. Robert, Nerodegeneration 4 (1995) 23-32.

[10] B. Seilheimer, B. Bohrmann, L. Bondolfi, F. Muller, D. Stuber, H. Dobeli, J. Struct. Biol. 119 (1997) 59-71.

[11] C.A. McLean, R.A. Cherny, F.W. Fraser, S.J. Fuller, M.J. Smith, K. Beyreuther, A.I Bush, C.L. Masters, Ann. Neurol. 46 (1999) 860-866.

[12] M.P. Lambert, A.K. Barlow, B.A. Chromy, C. Edwards, R. Freed, M. Liosatos, T.E. Morgan, I. Rozovsky, B. Trommer, K.L. Viola, P. Wals, C. Zhang, C.E. Finch, G.A. Krafft, W.L. Klein, Proc. Natl. Acad. Sci. U.S.A. 95 (1998) 6448-6453.

[13] M.S. Shearman, C.I. Ragan, L.L. Iversen, Proc. Natl. Acad. Sci. U.S.A. 91 (1994) 1470-1474.

[14] L. Meda, M.A. Cassatella, G.I. Szendrei, L. Otvos Jr., P. Baron, M. Villalba, D. Ferrari, F. Rossi, Nature 374 (1995) 647-650.
[15] S.S.-S. Wang, D.L. Rymer, T.A. Good, J. Biol. Chem. 276 (2001) 42027-42034

[16] S.S.-S. Wang, T.A. Good, D.L. Rymer, Int. J. Biochem. Cell Biol. 37 (2005) 1656-1669.

[17] O. Wirths, J. Weis, R. Kayed, T.C. Saido, T.A. Bayer, Neurobiol. Aging 28 (2007) 1689-1699.

[18] A.L. Fu, Z.H. Dong, M.-J. Sun, Brain Res. 1109 (2006) 201-206.

[19] A. Kakio, S.-I. Nishimoto, K. Yanagisawa, Y. Kozutsumi, K. Matsuzaki, Biochemistry 41 (2002) 7385-7390.

[20] M. Wakabayashi, T. Okada, Y. Kozutsumi, K. Matsuzaki, Biochem. Biophys. Res. Commun. 328 (2005) 1019-1023.

[21] A. Kakio, S.-I. Nishimoto, K. Yanagisawa, Y. Kozutsumi, K. Matsuzaki, J. Biol. Chem. 276 (2001) 24985-24990.

[22] Z.-X. Sun, Q.-H. Zhou, S.-F. Sui, Neurosci. 391 (2005) 71-75.

[23] Y. Nagai, Behav., Brain Res. 66 (1995) 99-104.

[24] D.Z. Liu, W.Y. Chen, L.M. Tasi, S.P. Yang, Colloids Surf. A 172 (2000) 57-67.

[25] J.A. Lundbaek, P. Birn, J. Girshman, A.J. Hansen, O.S. Anderson, Biochemistry 35 (1996) 3825-3830.

[26] L.Y. Chen, J.J. Lin, M.S. Lin, S.M. Chiu, W.Y. Chen, Colloids Surf. A 296 (2007) 86-91.

[27] L.-P. ChooSmith, W. Garzon-Rodriguez, C.G. Glabe, W.K. Surewicz, J. Biol. Chem. 272 (1997) 22987-22990.

[28] K. Yanagisawa, A. Odaka, N. Suzuki, Y. Ihara, Nat. Med. 1 (1995) 1062-1066.

[29] N. Arispe, M. Doh, FASEB 16 (2006) 1526-1536.

[30] A. Schneider, W. Schulz-Achaeffer, T. Hartmann, J.B. Schulz, M. Simons, Neurobiol. Dis. 23 (2006) 573-577.

[31] M.S. Lin, H.M. Chiu, F.J. Fan, H.T. Tsai, S.S.S. Wang, Y. Chang, W.Y. Chen, Colloids Surf. B 58 (2007) 231-236.

[32] R. Kayed, E. Head, J.L. Thompson, T.M. Mclntire, S.C. Milton, C.W. Cotman, C.G. Glabe, Science 300 (2003) 486-489.

[33] D.J. Selkoe, Nature 399 (1999) A23-A31.

[34] J. Hardy, Trends Neurosci. 20 (1997) 154-159.

[35] K. Iqbal, I. Grundke-Iqbal, J. Alzheimers Dis. 4 (2002) 235-238.

[36] S.R. Ji, Y. Wu, S.F. Sui, J. Biol. Chem. 277 (2002) 6273-6279.

[37] J.A. Carson, A.J. Turner, J. Neurochem. 81 (2002) 1-8. 